\title{
THE LEGAL EFFECT OF INSOLVENCY ON BANK DEPOSITS
}

\section{D. Coviti $\dagger$}

\section{Introductory}

Before proceeding with the main topic, it may perhaps be worthwhile to state briefly the general law governing deposits. Bank deposits may be of two kinds: general and special. In the case of the general deposit, the legal relationship is that of debtor and creditor, while in the case of special deposit, it may, technically, be either bailor and bailee, principal and agent, or trustee and cestui que trust. ${ }^{1}$ Under the debtor and creditor relationship, title to the res passes instantly with the deposit to the depositee, the latter being free to deal with it as he chooses and becoming liable to the depositor for an equivalent amount. The depositor in his turn becomes a general creditor. Under the bailee and bailor relationship, title to the res does not pass to the depositee but only possession, and, presumably, as in cases of bailment of chattels other than money, a general lien on the res will result in favor of the bailee, permitting him to hold it as security for payment of charges that may grow out of the contract of bailment. Under the principal and agency relationship, technically, neither title nor possession but only custody passes to the agent. The agent can do no more than what his express or implied authority from the principal will permit him to do, nor has he in point of theory even a lien on the res. To support a lien possession will be necessary, and that he would not have if the res comes to him from the depositor directly, or has been first reduced to the possession of the depositor. Under the trustee and cestui que trust relationship, the legal title passes to the trustee while the equitable title rests in the cestui que trust. In any of the last three named relationships the res itself, in its original or changed form, and the proceeds when converted into money that can be traced, must

$\dagger$ Dean, Miami College of Law. B. A., University of Kentucky, 1913; M. A., Clark University, I9I5; J. D., Northwestern University, 1924. Instructor, University of Louisville Law School, 1924-28; University of Miami Law School, 1928-32; Vanderbiit Unisity Law School, summer sessions, I929-30. Contributor to anthropological and legal journals. For a more detailed treatment of some phases of the present topic by the same author, see Acceplance of Deposits by Banks When Insolvent, in the FLORIDA BAR AssoCIATION LAW JoURNaI, for April, I93I.

${ }^{1}$ See Commercial Bank of Pa. v. Armstrong, I48 U. S. 50, I3 Sup. Ct. 533 (1892); Collins v. State, 33 Fla. 429, I5 So. 214 (1894), and authorities cited; Camp v. First National Bank, 44 Fla. 497, 33 So. 24I (1902); City Bank of Fort Lauderdale v. Hart, I36 So. 446 (Fla. I93I) ; Miami v. Shutts, 59 Fla. 462, 5I So. 929 (Igro) ; see also Mallett v. Tunnicliffe, I37 So. 238 (Fla. I93I), holding that an attempt to withdraw the deposits will terminate the debtor-creditor relationship and constitute the bank a trustee; see also Baker, Bank Deposits and Collections (I9I3) II MICH. L. REv. I22 (commenting upon application of principal and agent); Turner, Deposits of Demand Paper as "Purchases" (I928); 37 YALE L. J. 874. 
be preserved and kept intact, and will, except as against a third party who is a bona fide purchaser for value without notice, put the depositor in the position of a preferred claimant.

There is no set criterion by which a deposit may be determined to be general or special. To be sure, in the final analysis, it is the mutual intent as ascertained from either expressed provisions and agreements, or implied from the nature of the dealings and conduct of the parties, and the custom prevailing in the locus in quo that governs. Indorsements of commercial paper, however, have been variously treated and construed by the court. Thus, if matured or demand paper is endorsed to a bank "for collection" or "for deposit", the deposit is said to be presumptively at least, a special deposit, and the bank will not become a debtor until it is paid. A like presumption is said to obtain if such paper is endorsed "for deposit to the credit of" the depositor. But if such paper is endorsed "for collection and credit", the above presumption has not been applied by some courts, and the bank is treated as a debtor from the time the deposit was made. ${ }^{2}$ Again, if matured or demand paper is endorsed in blank, without anything more, and if credit be given at the time of the deposit to the depositor, there are decisions holding both ways. The majority hold that the bank becomes at once a debtor, while with other courts it becomes only a special depositee or trustee. ${ }^{3}$ Collection, by the weight of authority, has been held to change the legal relation of the parties, making the depositee a debtor as soon as collection is made and credited irrespective of the nature of the indorsement. ${ }^{4}$ But, even after collection, sometimes by undue refinement, the mere use of a particular word or words by way of direction, although done perhaps inadvertently, has been seized upon by some courts in deciding one way or another. Thus, where paper was sent "for collection and remittance", "for account", or "for collection and return", ${ }^{6}$ it was held that collection will not terminate the special deposit. On the other hand, when there was a direction "forward draft to me for balance less your fees", it was held that the collecting bank will become a debtor to the owner of the note immediately after collection, the court construing the word "draft" as indicative of an intent on the part of the sender not to make the money collected a

See Nyssa Arcadia Drainage District v. First National Bank, etc., 3 F. (2d) 648 (I925), and ScotT, Selected Cases and Other Authorities on the Law of Trusts (Ist ed. Ig19) $64 \mathrm{n}$.

${ }^{3}$ Halloway v. Dykes, 29 F. (2d) 430 (1928); Scorr, op. cit. supra note 2, at 66, 67. Cf. Williams v. State, 139 So. 393 (Miss. 1932), where acknowledgment from the bank was accompanied by notice that the bank would act only as a collecting agent.

- Raynor v. Scandinavian, etc. Bank, I22 Wash. I50, 210 Pac. 499 (I922); State v. Banking Corp., 77 Mont. I34, 25I Pac. I5I (1926); Walker v. McNeill, o8 Fla. I8I, 66 So. 994 (I914), the latter holding trust because the paper was not yet collected; Williams v. State, supra note 3 .

${ }^{\circ}$ Scotr, op. cit. supra note 2 , at 68.

${ }^{\circ}$ Nyssa Arcadia Drainage District v. First National Bank, etc., supra note 2. 
special deposit. ${ }^{7}$ It has also been held that a debtor-creditor relationship arose after collection where the paper was marked "for collection or return".8

It would seem that under the view taken by the latter opinions the deposit should be general in those cases even before collection since ultimately it is the intent that determines the relationship, and if the use of the word "draft", for instance, is in itself sufficient to indicate an intent not to make the money a special deposit after collection, why should not the same intent control from the very time of deposit? By analogy, the situation where the word "remit" is used was construed as indicative of an intent to continue a deposit as a special deposit even after collection. ${ }^{9}$

The nature of the dealings between the parties and their business customs have likewise been treated ambiguously by the courts; thus, in one federal case the court has this to say:

"The practice, which has grown up among banks, to credit such deposit at once to the credit of the depositor, and to allow him to draw aganst them before the collection has been made, is reckoned by the ablest text writers a mere gratuitous privilege which does not grow into a binding legal usage." 10

Under this decision, therefore, a mere deposit of a check by a customer will not pass title until collected, despite customary dealing on a cash basis.

Other cases, however, are of the opposite effect. In First National Bank of Elkhart v. Armstrong, ${ }^{11}$ for example, the court disregarded the indorsement "for collection for the First National Bank of Elkhart" and because of customary dealing and understanding between the two banks to credit the deposits as cash subject to payment, and to allow drawing against such deposits, held that title to the deposits passed to the collecting bank immediately, and the forwarding bank had the rights of a general creditor only.

The fact that an account is overdrawn is generally held to pass title to paper deposited for collection, ${ }^{12}$ perhaps because the bank is in the position

${ }^{7}$ Sayles v. Cox, 95 Tenn. 579, $3 z$ S. W. 626 (1895), citing Aiken v. Jones, 93 Tenn. 353, 27 S. W. 669 (I894); I MoRSE, BANKS AND BANKING (6th ed. Ig28) $\$ 305$.

${ }^{8}$ State v. McKinley County Bank, 32 N. M. I47, 252 Pac. 980 (I927).

${ }^{9}$ Turner, Bank Collections-The Direct Routing Practice (1930) 39 Y ALE L. J. 468 (criticizing view of termination of agency after collection).

${ }_{10} \mathrm{St}$. Louis \& S. F. Ry. v. Johnston, 133 U. S. 566, 10 Sup. Ct. 390 (1890), rev'g 27 Fed. 243 (C. C. S. D. N. Y. I886) ; see also Balbach ct al. v. Frelinghuysen, I5 Fed. 675 (C. C. D. N. J. 1883), citing Morse, op. cit. supra note 7, at 522. Similar in effect is First Nationai Bank v. Armstrong, 42 Fed. 193 (C. C. S. D. Ohio 1890), where the court gave more weight to the words "for collection" used in the endorsement and the words "subject to payment" used in the crediting of the deposit, than to the customary dealings between the parties, by which the paper would be credited to the depositor immediately upon deposit and would become at once subject to draft and interest on daily balance.

${ }_{11} 39$ Fcd. 23I (C. C. S. D. Ohio I889). Of like effect is Franklin County National Bank v. Beal, 49 Fed. 606 (C. C. D. Mass. I892), except that in the latter case the endorsement was "for collection and credit". The use of the word "credit" may be of some significance in showing an intent to pass title, Nyssa Arcadia Drainage District v. First $\mathrm{Na}$ tional Bank ctc., supra note 2.

${ }_{12}$ See note to Sayles v. Cox, supra note 7, in 32 L. R. A. 715 (I856), and Balbach et al. v. Frelinghuysen, supra note Io. 
of a bona fide purchaser for value without notice, in jurisdictions where antecedent debts are sufficient to constitute "value".

Outward expressions and acts are taken generally as determinative of intention, but the decisions on this point are not uniform, especially where only one party does the act. Thus, a deposit kept apart by the bank was held not to be a special deposit on the ground that the intention to treat it as a special deposit was undisclosed and unknown to the depositor. ${ }^{13}$ However, it would seem that where the keeping apart is for the benefit of the depositor, as was the case here, consent on his part should be presumed, just as it is ordinarily presumed in cases of gifts and benefits under a trust.

This necessity for construction and the accompanying difficulties attendant upon deposits of commercial paper is generally obviated where the deposits are in cash, and they may be said to stand in the same position as deposits of paper after collection, which, under the majority rule, will ordinarily pass title from the time of receipt, subject to the qualifications indicated above and those to be indicated hereafter.

\section{Effect of Insolvency}

The leading case in this country with regard to the effect of insolvency is St. Louis and S. F. Railway Co. v. Johnston. ${ }^{1+}$ The case may be said to have established firmly the general rule since followed by the great majority of jurisdictions in this country. ${ }^{15}$ The rule is that when a bank is hopelessly insolvent, and this fact is known to its officers but not to its depositors, the receipt of money on general deposit is a fraud on the depositor and will raise a trust enabling him to reclaim the deposit.

It is worthy of mention that in the case just cited the deposit was by a draft, which was not collected at the time the bank closed its doors, and while the court favored the view that mere crediting of the draft on the books of the bank and allowing the depositor to draw against the credit did not pass title to the bank, so that the decision could have been rested on the ground that the bank was the agent of the depositor, it nevertheless preferred the ground of fraud.

Various theories have been suggested with regard to the legal operation of the above rule. With some courts it would seem that the acceptance of deposits with knowledge of hopeless insolvency is characterized as a fraud so that the party is entitled to rescind the transaction and recover the deposit, thus implying that title has passed but that the transaction is voidable at the will of the depositor; with others, the effect of the fraud is not to pass title

${ }^{13}$ Washington etc. Manufacturing Co. v. Duke, I26 Wash. 510, 218 Pac. 232, 37 A. L. IR. 611, 6I7 (I923), and collected cases cited therein.

"S Sipra note Io.

${ }^{25}$ See annotation to Winifred Steele v. Allen et al., in (1922) 20 A. L. R. I206, giving copious citations for the various states, Canada and England, adhering to the same rule. 
at all, so that the property to the deposit is said to remain in the depositor subject to his orders, the banker presimably standing in the position of bailee or agent; while still others adopt the view that the fraud will create a trust ex maleficio. ${ }^{16}$

It must be said, however, that the language of the courts is often confusing, and does not indicate clearly which one of these theories is preferred. Thus, in one case, the court said:

"The reception of the money and checks, under such circumstances, was a fraud upon the plaintiff, and entitled him to rescind the transaction, and recover back his deposit from the bank. The keeping of the bank open, and the conducting of its business in the usual manner, constituted a representation to its customers of the solvency of the bank, upon which they had the right to rely; and, if the bank was known to be insolvent by the officers who were charged with its management, the concealment of that fact from a person about to make a deposit would constitute a fraud upon him. The title acquired by the bank to the money and checks deposited under such circumstances would be voidable at the election of the depositor, who could bring suit to recover his deposit without any previous demand. The bank would become a trustee ex maleficio, and would hold the deposit for the use of the depositor, and subject to his right of reclamation." 17

The court here relies not only upon the idea of rescission, which necessarily presupposes title to have passed, but also upon the idea of a trust $e x$ maleficio, which in point of theory would presuppose a split of title with the legal title resting in the bank as trustee and the equitable title in the beneficiary or, in this case, the depositor. ${ }^{18}$

However, no matter which be the theory relied upon, the legal effect is the same. By either theory the depositor. will hav th right to recover the whole of the deposit without having to come in and share pro rata as a general creditor, except perhaps so far as the question of the election of remedies is concerned. ${ }^{19}$

${ }^{10}$ Ames, Follozing Misappropriated Property into its Product (Ig06) 19 Harv. L. Rev. SII; Scott, The Right to Follow Money Wrongfully Mingled with Other Money (1913) 27 HaRv. L. REv. I25, and note in (I922) 20 A. L. R. I206.

${ }^{17}$ Wasson v. Hawkins, 59 Fed. 233 at 234 (C. C. D. Ind. 1894).

${ }^{18}$ Accord: Lake Erie \& W. R. Co. v. Indianapolis National Bank, 65 Fed. 690 (C. C. D. Ind. I895); Quin v. Earle, 95 Fed. 728 (C. C. E. D. Pa. 1899); Richardson v. New Orleans Coffee Co., I02 Fed. 785 (C. C. A. 5th, Ig00) (confusing agency and trust); Butler v. Western German Bank, I59 Fed. II6 (C. C. A. 5th, I908) (failing to preserve a like distinction with regard to the question of interest on the deposit); Brennan v. Tillinghast, 20I Fed. 609 (C. C. A. 6th, 1913); Hutchinson v. National Bank of Commerce, 145 Ala. 196,4 I So. I43 (1906).

${ }^{10}$ See in this connection Ames, supra note I6, suggesting that under the constructive trust theory, if money of the depositor is wrongfully mixed by the wrongdoer with an equal amount of his own money, and part of it withdrawn, the claimant would be entitled only to half of what is left, he being a co-owner of the whole or every part of the whole. See also Scott, supra note 16. 
The practical application of the general rule allowing recovery of the whole deposit requires the presence of certain conditions, and these in turn give rise to considerable refinement and controversy by the courts.

These conditions are: (I) the bank must be hopelessly insolvent; (2) the officers of the bank must have knowledge of the insolvency; (3) the funds must be capable of identification or tracing in the hands of the receiver or liquidator; (4) they must not have come into the hands of a bona fide purchaser for value without notice. Most of the controversy rages over the construction of these conditions, particularly with regard to knowledge and tracing, the weight of authority favoring a liberal construction; the minority, a strict construction. ${ }^{20}$

Thus, by the majority, knowledge need not be accompanied by actual intent to defraud. ${ }^{21}$ In St. Louis and S. F. Railway Co. v. Johnston, ${ }^{22}$ it was held sufficient that the president of the bank knew of its insolvency.

In one case, after declaring it error to require affirmative proof that the officers knew of the insolvency, and quoting Wigmore, ${ }^{23}$ who recites various indications pointing to the probability that a given person obtained knowledge, one of which is the surrounding circumstances, or what Wigmore calls "the quality of the occurrence", the court continues:

"We will not further quote from this philosophical discussion, but will be content with the observation that one who was impelled on one day to make an assignment for the benefit of creditors because of an insolvency so hopeless as was the case here must have been in such direct exposure . . . to the facts as to have charged him with knowledge of their existence. And the quality of the occurrence . . . speaks very strongly to the belief that . . . the conditions bringing about such occurrence were known to the actors." 24

And this from a Washington court:

"The keeping of a bank open in the usual manner for the transaction of business is a representation to every person dealing with it that the bank is able to keep and perform its contracts and that the person so dealing takes upon himself nothing more than the ordinary risks incident to the business; in other words, it is a representation that the bank is solvent. If the fact be that the bank is insolvent, the representation so made is a false representation, . . . ." 25

Knowledge of an agent of employee of a bank is generally sufficient if the wrong-doing has extended over a considerable length of time and the

${ }^{m}$ I STORY, EQUTTY JuRISPRUdence (I4th ed. I918) $\$ \$ 187-265$; I PerRY, Trusts (7th ed. 1929) \& I8I; 2 MORSE, op. cit. supra, note 7 at I237-1239, I320-I329; BOGERT, TRUSTS (I92I) I2I; TIFFANY, BANKS AND BANKING (I9I2) \$29; and cases cited infra note 29.

${ }_{2}$ This is really applying the test used in tort and criminal actions, as to what a reasonable prudent person would have anticipated and done under similar circumstances.

$=$ Supra note IO.

23 I WIGMORE, ETIDENCE (Ist ed. 1904) § 245.

2 In re Silver, 208 Fed. 797 at 799 (N. D. Ohio 1912).

$\approx$ Raynor v. Scandinavian Bank, supra note 4, at 159, 210 Pac. at 503. 
agent is the only one representing the bank in the particular transaction. In a leading Massachusetts case where the question was whether an act of embezzlement on the part of the treasurer of a corporation and the knowledge of it should be imputed to the principal, the court in answering in the affirmative, says :

"It is true, that no officer of the plaintiff besides Gray knew of the fraudulent origin of these checks; but, in the very transaction of receiving them, the plaintiff was represented by Gray, and by him alone, and is bound by his knowledge. It is the same as if the plaintiff's directors had received the checks knowing what he knew." 26

To satisfy tracing and augmentation, by the majority rule, it is sufficient that the money in question be traced into and augment the common mass, and that it be not dissipated prior to its coming into the hands of a receiver or liquidator.

Thus, according to Knatchbull $v$. Hallett, ${ }^{27}$ the leading English case on the subject of tracing, money when fraudulently mixed with other money becomes impressed with a trust, so that subsequently, when money is paid out of the mixed mass it will be considered as coming from that part which legally may be dispersed, the court proceeding on the idea that a trustee is honest rather than dishonest and will be presumed to pay out money that he may properly pay out. The only requirement under this rule is that there be enough money at all times, $i$. e., from the time of confusion to the time of failure, equal to or greater than the sum claimed; it would not be necessary for the money to be kept separate or the identical money preserved. ${ }^{28}$ The cases in this country have generally adopted the rule laid down in $K$ natchbull $v$. Hallett. ${ }^{29}$

In Richardson $v$. New Orleans Debenture Redemption Co., the court in alluding to the former doctrine requiring identity says this:

${ }^{23}$ Atlanta Cotton Mills v. Indiana Mills, I47 Mass. 268, at 273, I7 N. E. 496 at 501 (r888). Clark Sparks \& Sons Mule \& Horse Co. v. Americus National Bank, 230 Fed. 738 (S. D. Ga. 1916) ; Martin v. First National Bank of Rush City, 5I F. (2d) 840 (D. C. D. Minn. I931); Orme v. Baker, 74 Ohio St. 337, 78 N. E. 439 (1906). What applies to embezzlement would all the more apply to a civil case, as in criminal actions the tendency is not to impute the act of the agent to the principal where the former is not an innocent party. Ch. 62 .

${ }^{27}{ }_{13}$ Ch. D. 696 (I880). See also James Roscoe (Bolton), Ltd. v. Winder, [1915] I

${ }^{2}$ The decision in Knatchbull v. Hallett, supra note 27 , has been somewhat modified by In re Oatway [1903] $2 \mathrm{Ch} .356$.

$\approx$ National Bank v. Insurance Co., 104 U. S. 54 (I88I) ; Peters v. Bain, I33 U. S. 670, I0 Sup. Ct. 354 (I890); Schuyler v. Littlefield, 232 U. S. 707, 34 Sup. Ct. 466 (I9I4); Hirning v. Federal Reserve Bank of Minneapolis, 52 F. (2d) 382 (C. C. A. 8th, I93r); Bank of Springfield v. Therrell, I38 So. 733 (Fla. I932); Shaw v. McCord, 18 S. W. (2d) 200 (Tex. I929); cf. McGregor v. Battle, 128 Ga. 577, 58 S. E. 28 (I907); Hughes v. Lake, 63 Miss. 552 (1886); Wilson v. Coburn, 35 Neb. 530,53 N. W. 466 (1892); Perth Amboy Gas Light Co. v. Middlesex Bank, 60 N. J. Eq. 84, 45 At1. 704 (I900), and cases cited therein: Commercial \& Farmers National Bank of Baltimore v. Davis, II5 N. C. 226 , 20 S. E. 370 (1894); Venner v. Cox, 35 S. W. 769 (Tenn. I895); Sayles v. Cox, supra note 7 . 
"The equitable right of following misapplied money . . . depended on identifying it, the equity attaching to the very property misapplied. Money . . . had no earmarks, and the tracing of the fund would fail. This view was manifestly inequitable and unjust, and so, finally, it was held that confusion by commingling does not destroy the equity, but converts it into a charge upon the entire mass, giving to the party injured by the unlawful diversion of the fund a priority of right over the other creditors of the possessor and wrongdoer . . . To create the trust it is not necessary to show that the identical money went into the hands of the receiver. It is sufficient if the funds in his hands are increased by the deposit." 30

In Sanders $v$. Stevens, ${ }^{31}$ the court denied preference to the drawer of a check, where the proceeds were set off by a corresponding bank against the defunct bank's indebtedness on the ground that since the money had never been mixed with the assets of the defunct bank, there was no such augmentation of assets as is necessary.

In Cuttell v. Fluent, ${ }^{32}$ the court refused priority where the draft went to a correspondent bank, which collected and credited it to the account of the insolvent bank. At the time the draft was credited to the insolvent bank the latter had a credit balance with the correspondent bank, but the account was overdrawn when the insolvent bank was taken over by the comptroller of currency. There was no evidence that any proceeds of the draft, directly or by substitution, at any time were commingled with the cash funds of the insolvent bank coming into the hands of the receiver. Because of the latter circumstance the court held that there was no augmentation of the assets of the insolvent bank.

Of like effect is Schumacher $v$. Harriett, ${ }^{33}$ except that in the latter case the court held that it is a sufficient commingling and augmentation of assets merely to deposit checks to the credit of the depositor, considering these checks as cash because of their being treated as cash. The court said: ${ }^{34}$

"Under modern banking conditions, the rule as stated should be held to apply to cash items received by a bank under a trust agreement as well as to cash so received. Such an item for all practical purposes differs not at all from currency. It increases the cash funds of the bank just as much as does the deposit of currency. If the bank cashes it and covers the proceeds into its vaults, the augmentation, of course, is apparent. If, however, the bank treats the cash item as its own and

${ }^{30}$ 102 Fed. 780 , at 783 (C. C. A. 5th, Ig00). To the same effect are Western German Bank v. Norvell, I34 Fed. 724 (C. C. A. 5th, I905); Clark Sparks \& Sons Mule \& Horse Co. v. Americus National Bank, supra note 26; Nyssa Arcadia Drainage District v. First National Bank, supra note 2 .

${ }^{31} 5 \mathrm{I}$ F. (2d) 743 (S. D. Miss. I93I).

* $5 \mathrm{I}$ F. (2d) 974 (C. C. A. 8th, 1931). To the same effect is Larabee Flour Mills v. First National Bank of Dublin, 52 F. (2d) I46 (S. D. Ga. 193I).

$\approx 52$ F. (2d) 8I7 (C. C. A. 4th, I93I).

84 . at 819,820 . 
uses it for other banking purposes, such as payment of debts or creating credits in other banks, the cash in the vaults of the bank is relieved to that extent; and, where a trust with respect to a cash item is involved, it must be presumed that the intention was that cash remaining in the vaults of the bank is to be substituted under the trust. . . . In other words, we think that a cash item, which is accepted by a bank as cash . . must be treated as cash in determining whether the cash remaining in the bank is subject to a trust because of the commingling of trust funds."

The concept of augmentation is somewhat further extended by the same court in Schumacher $v$. Brinson, ${ }^{35}$ decided on the same day as the previous case, where the court treated what was virtually a mere charging of the depositor's account with a certain amount and crediting the bank bond account as amounting to an augmentation. In the words of the court:

"It can make no difference that, instead of cashing a check and then delivering the money to the bank for the purchase of the bonds, he allowed his account to be charged with the amount necessary. The bank had on hand funds more than sufficient for the purpose, and by the agreement with complainant they were impressed with a trust in his favor. . . . The reason underlying the rule is that, by agreement between the parties, a general deposit may be converted into a special deposit. . . . What we have is in effect an agreement by the bank that a definite amount of the funds in its possession shall be held in trust for a specified purpose. In cther words, what the record discloses is, not a shifting of credits, but the creation of a trust with respect to funds already in the bank's possession."

While the current view, as seen from the above excerpts, marks quite a departure and liberalization of the old view, it would seem that in some respects it is not liberal enough, and that apparently the courts in their anxiety not to break away entirely from the former rule have been clinging, to use a broad metaphor, to some of the remains after body and spirit have gone.

The first aspect that suggests itself for discussion is the well-established requirement that in order to satisfy tracing or identification, it must appear that enough money was present in the bank from the time of deposit to the appointment of a receiver or liquidator to cover the claim in question, or, expressed negatively, that a trust will not attach except to the minimum

${ }^{85} 52$ F. (2d) 821 at 822 (C. C. A. 4th, I93I). To be sure, from the above, it would seem that the court considered what was done in that case as the creation of a trust out of a general deposit, and not a shifting of credits. It is submitted, however, that that is perhaps a distinction without a difference, since the setting aside was nothing more than a mere shifting of credit. The court seems to be somewhat illogical when it speaks of a trust by augmentation as distinguished from a trust by agreement, as if augmentation could of itself create a trust. As a matter of fact, it is merely an element or condition necessary to constructive fraud and should be the same even if the trust had been created by agreement. In other words, what the court is doing is merely calling the same thing by different names. The case has been very recently reversed by the Supreme Court; 52 Sup. Ct. 516 (I932). 
constant balance remaining in the bank for the interval in question. ${ }^{36}$ One asks first what practical difference that makes.

It is perhaps not too far removed to draw analogies from the common law. Such an one would be the sale and mixture of fungible goods. A sale of such goods may be effected under the Sales Act even though the goods be undivided, and the number, weight, and measure unascertained. If the quantity sold is less than is contained in the mass at the time, title will still pass, the seller having to make good the deficiency from similar goods. ${ }^{37}$

But even before the adoption of the Sales Act, opinion in this country tended towards a similar view. Particularly in point is a Minnesota case, Hall $v$. Pillsbury. ${ }^{38}$ In that case suit was brought to recover the value of certain grain which had been purchased by the defendants from a warehouseman with whom the plaintiffs had deposited it for safe keeping. A Minnesota statute provided that "No person receiving or holding grain in store shall sell or otherwise dispose of, or deliver out of the storehouse or warehouse where such grain is held or stored, the same, or any part thereof, without the express authority of the owner of such grain, and the return of the receipt given for the same, except as herein provided." By another section, the delivery of grain for deposit with the warehouseman was expressly made a bailment and not a sale, changing, as the court points out, the common law practice of viewing it as a sale and not a bailment. The court in construing the statute said:

"The declaration that the delivery shall be deemed and treated as a bailment must be taken as meaning that the depositor shall be deemed

${ }^{38}$ That requirement has been somewhat modified as suggested in note 28 , supra, by $I n$ re Oatway, where the court allowed a recovery of certain trust funds from a confused mass by tracing them into shares of stock purchased with a part of the commingled fund, even though the money left to satisfy the trust claim, sufficient when the stock was purchased, was later used for other purposes. But that recovery was only allowed because of tracing the money into specific property, the court taking the view that the trust money had merely changed in form. That court apparently would not have allowed recovery if all of the commingled mass had been dissipated and no part of it could be traced, even though subsequently there may have been redeposits sufficient to cover the trust funds at the time of demand. See in this connection First National Bank v. Littlefield, 226 U. S. I Io, 33 Sup. Ct. 78 (I912), aff'g In re Brown, I93 Fed. 24 (C. C. A. 2d, I912); Board of Commissioners v. Strawn, I57 Fed. 49 (C. C. A. 6th, ro07); Primtau v. Granfield, I84 Fed. 480 (C. C. S. D. N. Y. IgII), reversed on another ground in I93 Fed. 9II (C. C. A. 2d, IgII); In re City Bank of Dowagiac, I86 Fed. 413 (W. D. Mich. I919); In re A. O. Brown \& Co., I89 Fed. 432 (S. D. N. Y. IgII); Brennan v. Tillinghast, supra note I8.

"The UNIForM SALES ACT, $\$ 6$, I U. L. A. 77 (I93I), provides: "(I) There may be a contract to sell or a sale of an undivided share of goods. If the parties intend to effect a present sale, the buyer, by force of the agreement, becomes an owner in common with the owner or owners of the remaining shares. (2) In the case of fungible goods, there may be a sale of undivided share of a specific mass, though the seller purports to sell and the buyer to buy a definite number, weight or measure of the goods in the mass, and though the number, weight or measure of the goods in the mass is undetermined. By such a sale the buyer becomes owner in common of such a share of the mass as the number, weight or measure bought bears to the number, weight or measure of the mass. If the mass contains less than the number, weight or measure bought, the buyer becomes the owner of the whole mass and the seller is bound to make good the deficiency from similar goods unless a contrary intent appears." The Sales Act is now law in the majority of the states and in the territory of Alaska.

${ }^{2} 43$ Minn. 33, 44 N. W. 673 (1890). 
to be the owner of, and to have on bailment in the warehouse, the amount of grain that he deposits, although its identity may have been lost by commingling with other, the like kind of grain, and although not a kernel of the identical grain deposited still remains. As fast as grain is removed, and other grain is put into the common mass, the new grain takes the place of that originally deposited, and is appropriated to the contract of bailment, so as to become the property of the depositor. . . But, while the interest of the depositor in the mass is measured by the amount he deposits, and mentioned in his receipt, the interest of the warehouseman, by reason of putting his own grain into the mass, is not necessarily measured by what he puts in ; for if, from any cause for which he is responsible, as by his taking grain out from the mass, the whole amount is diminished below what is required to fill the outstanding receipts, what he puts in is appropriated at once, so far as may be necessary, to the receipts, and becomes at once the property of the holders. . . . It is true, it may be the practice-probably isof warehousemen to take out and dispose of grain without reference to the relation which the amount in warehouse bears to the amount of the outstanding receipts. . . . When this is done with the consent (such as the statute requires) of the depositors, it is, of course, rightfully done; and in that case a sale by the warehouseman would pass the title. No presumption of consent on the part of the depositor could arise from the existence, however general, of such a practice. Such a practice is made unlaw ful." 39

The writer is not unmindful of the fact that the above case had to do with bailments, upon the theory of which no title passes to the bailor. It is submitted, however, that the factor of identification and tracing is the same in either trust or bailment, and what is sufficient in one should be sufficient in the other. This is particularly true where the view taken by the courts with regard to the acceptance of deposits by banks under fraudulent circumstances is either that no title passes or that the fraud avoids the passing of title. In either case the depositee, because of the fraud, will stand in the position of a bailee; in the first, because title never passed; in the second, because title will revert to the depositor.

Another analogy is suggested by the marginal sales of stock cases. Two views seem to be prevalent; one, the majority view known as the New York rule, the other, the minority or Massachusetts. Under the New York rule, the relation between a buyer on margin and a broker is that of pledgor and pledgee, title being in the former. ${ }^{40}$ Under the Massachusetts rule, title

${ }^{\approx} I d$. at 35,44 N. W, at 673 . See also Woodward v. Semans, 125 Ind. 330, 25 N. E. 440 (1890) ; Arthur v. Chicago Ry., 6r Iowa 648, I7 N. W. 24 (I883) ; Moses v. Teetors, 64 Kan. I49, 67 Pac. 526 (Ig02) ; Forbes v. Boston \& L. R. R., I33 Mass. I54 (I882); Ledyard v. Hibbard, 48 Mich. 42I (1882) : Savage v. Salem Co., 48 Ore. I, 85 Pac. 69 (I906); Bretz v. Diehle, II7 Pa. 589, II Atl. 893 (I888); Young v. Miles, 20 Wis. 6I5 (I866), 23 Wis. 643 (1869).

${ }^{20}$ Richardson v. Shaw, 209 U. S. 365, 28 Sup. Ct. 5 I2 (I908); Sexton v. Kessler, 225 U. S. 90,32 Sup. Ct. 657 (I912); Markham v. Jaudon, 4I N. Y. 235 (I869); Jones, Col- 
to stock remains in the broker, there being nothing more than an executory contract to sell to the buyer. ${ }^{41}$ In those jurisdictions which follow the New York view, in case of the bankruptcy of the stock broker, it has been held that if the original securities are unavailable, the marginal buyer or "Iong" customer may claim other securities of the same kind, on the theory with some courts that there is a presumption that the new securities were intended by the broker to replace the original; with other courts, stocks are likened to fungible goods. ${ }^{42}$

In either view it would not be necessary that the identical security be obtainable to satisfy tracing, nor that any constant supply of the same kind of securities be on hand to satisfy demand by a customer at any time between pledging and the passing of the securities into the receiver's hands. Thus, in Duel v. Hollins, ${ }^{43}$ the Court held that a customer may demand the delivery of stocks purchased for him, and such delivery may be made during insolvency without creating a preference under the Bankruptcy Act, even though, as the dissenting opinion points out, at the time of the inception of the bankruptcy proceedings, it did not appear that there were certificates enough in quantity in the broker's possession "equal in amount to those which should have been on hand". It also appeared that the broker, having sold the original certificates, had not bought others of like kind nor kept on hand sufficient to satisfy the several claims, and that out of 200 shares claimed, the roo shares on hand were not acquired with the intent to make restitution. Justice McReynolds, in delivering the majority opinion, and restating the language used in Gorman v. Littlefield, ${ }^{44}$ said:

"It was held that the certificates of stock were not the property itself, but merely the evidence of it, and that a certificate for the same number of shares represented precisely the same kind and value of prop-

IAteral Securtties aNd Pledges (3rd ed. IgI2) \$495; Smith, Margin Siocks (I922) 35 HaRv. L. Rev. 485; Note (I908) 8 CoL. L. Rev. 488; (IgOI) I5 HaRv. L. REv. 78; Note (Ig06) Is HARv. L. REv. 529 (suggesting that the broker is a mere mortgagee because the title of the stock is in his name); (I916) 30 HaRv. L. Rev. 80; I Dos PAssos, StockBRoKers and Stock-Exchanges (2d ed. 1905) I87, 25 I.

"Covell v. Loud, I3.5 Mass. 4I (I883). But see Smith, supra note 40 , where it is suggested that by later Massachusetts decisions the relationship of agency or trust is favored, citing Rice v. Winslow, 180 Mass. 500, 62 N. E. I057 (I902); Crehan v. Megargel et al., 235 Mass. 279, 126 N. E. 477 (1920). See also Tillinghast, Problems of Distribution in Bankrupties of Stockbrokcrs (I930) 44 HARV. L. REv. 65 (suggesting agency relationship, subject to hypothecation by broker); Note (Ig06) I9 HARv. I. Rev. 529; (IgI6) 30 HaRv. L. REV. 80 .

${ }^{2}$ Richardson v. Shaw, supra note 40; Sexton v. Kessler, supra note 40 ; Gorman v. Littlefield, 229 U. S. 19, 33 Sup. Ct. 690 (I913); In re Brown, 171 Fed. 254 (S. D. N. Y. Ig09); Caswell v. Putnam, I20 N. Y. I53, 24 N. E. 287 (I890). See (I9I6) 30 HARv. L. REv. 80, criticizing the presumption theory, and suggesting instead a constructive trust imposed by law on the wrongdoer to make specific reparation when possible. See also Oppenheimer, Rights and Obligations of Customers in Stockbroktrage Bankruptcies (1924) 37 HARV. L. REv. 860, criticizing both theories; the presumption theory because it does not correspond with the fact, and the grain in bin theory because unlike grain or storage receipt for gold coin, numbers and names of securities are proper earmarks.

24I U. S. 523, 36 Sup. Ct. 6I5 (I9I6).

4 Supra note 42 , at 23,33 Sup. Ct. at 69 r. 
erty as another certificate for a like number of shares in the same corporation; that the return of a different certificate or the substitution of one certificate for another made no material change in the property right of the customer; that such shares were unlike distinct articles of personal property, differing in kind or value, as a horse, wagon or harness, and that stock has no earmark which distinguishes one share from another, but is like grain of a uniform quality in an elevator, one bushel being of the same kind and value as another. . . .

"It is therefore unnecessary for a customer, where shares of stock of the same kind are in the hands of a broker, being held to satisfy his claims, to be able to put his finger upon the identical certificates of stock purchased for him. It is enough that the broker has shares of the same kind which are legally subject to the demand of the customer. And in this respect the trustee in bankruptcy is in the same position as the broker. . . . It was, as we have seen, the duty of the broker, if he sold the shares specifically purchased for the appellant, to buy others of like kind and to keep on hand subject to the order of the customer certificates sufficient for the legitimate demands upon him. . . .

"When the bankruptcy which occasioned Gorman v. Littlefield took place the broker's box contained certificates, not specifically allotted, for three hundred and fifty shares of the designated stock and the appellant's claim for two hundred and fifty was the only one presented by a customer. We held that under the circumstances no more definite identification was essential, and approved his contention."

From the above decision, all that is necessary to satisfy tracing in a case of this kind is that there be enough of the same kind of stock at the time of bankruptcy or demand, and it would seem a fortiori that that should be the test when dealing with money, since the latter is devoid of any such earmarks as certificates of stock may be said to have. ${ }^{45}$

On the other hand, if the presumption theory be applied, ${ }^{ \pm 6}$ there seems to be no good reason why it should apply any more in the one case than in the other, since it is a mere fiction.

Still another analogy may be found in the law of trusts as applicable to other classes of property. It seems to be quite settled that if a trustee wrongfully disposes of property held in trust and it comes into the hands of a bona fide purchaser for value without notice, the cestui que trust cannot recover from the bona fide purchaser, but if the latter should reconvey to the trustee, the cestui que trust can come in and recover from the trustee, despite the intervention of a bona fide purchaser. ${ }^{47}$

45 See Oppenheimer's criticism of the "grain in bin" theory, supra note 42.

${ }^{48}$ It would seem from the use made of the idea of substitution and intent to restore in the case quoted above that both theories are resorted to at the same time. See (IgI6) 30 HARv. L. REv. 80, suggesting the constructive trust hypothesis, which, of course, should apply equally well to both classes of cases.

${ }^{47}$ Williams v. Williams, II8 Mich. 477,76 N. W. 1039 (1898) ; see Schutt v. Large, 6 Barb. 373, 380 (N. Y. 1849); Church v. Ruland, 64 Pa. 432,444 (I870). 
The same reasoning should apply to cases where money has been wrongfully disposed of by the trustee, and other money later comes into his possession. Unlike other property, money has no earmarks, and therefore under the new tendency the identical money would not be necessary, and the trust should reattach.

A somewhat similar analogy may be found under the Negotiable Instruments Law, which qualifies the position of a holder with regard to the assertion of personal defenses. Thus, ordinarily, not only would a bona fide purchaser for value without notice take a negotiable instrument free from personal defenses, but the same privilege would extend to a subsequent holder who gets it through a bona fide purchaser for value without notice, although he himself have notice, the latter enjoying the superior equity of the former. But such subsequent holder would not come within this exception if he himself participate in "any fraud or illegality effecting the instrument", or if he "became bound on the instrument prior to the acquisition of such defective title." 48

If one turns from analogies to the logic and rationale of the matter, one finds no support there. The argument commonly made and the reason commonly given as to why enough or more money should appear to have been constantly present in the common mass as will cover the claim asserted, is that in making withdrawals out of the common mass the depositor is presumed not to draw in order of time of deposit as the Clayton case ${ }^{49}$ would have it, but to draw first his own or such other money' as he may lawfully draw. There is a presumption of honesty that he will do this, and so long as enough to cover a given claim remains, it will be considered as if the original sum in question had been preserved intact; on the other hand, as soon as more than what is claimed is withdrawn, the original deposit in ques-

${ }^{4} \S 58$ of the N. I. L. now adopted in the majority of the states and territories provides: "In the hands of any holder other, than a holder in due course, a negotiable instrument is subject to the same defenses as if it were non-negotiable. But a holder who derives his title through a holder in due course, and who is not himself a party to any fraud or illegality affecting the instrument, has all the rights of such former holder in respect to all parties prior to the latter."

$\$ 59$ provides: "Every holder is deemed prima facie to be a holder in due course; but when it is shown that the title of any person who has negotiated the instrument was defective, the burden is on the holder to prove that he or some person under whom he claims acquired the title as holder in due course. But the last mentioned rule does not apply in favor of a party who became bound on the instrument prior to the acquisition of such defective title." See in this connection Berenson v. Conant el al., 214 Mass. I27, ror N. E. 60 (Igr3): Central National Bank v. Ericson, 92 Neb. 396, 138 N. W. 563 (Igr2); Bute v. Williams, 162 S. W. 989 (Tex. Civ. App., 1913). In the latter case the court said at 994: "The rule is uncontroverted that the payee of a note which has been procured by fraud, or as to which there are defenses between the original parties, either based upon fraud or illegality of consideration, cannot, after the transfer of the note to an innocent purchaser for value, repurchase same and enforce it against the maker stripped of its defenses in favor of the maker." Citing Elwell v. Tatum, 6 Tex. Civ. App. 397, 24 S. W. 7I (1893), 25 S. W. 434 (1894). Cf. Horan v. Mason, I4I App. Div. 89, I25 N. Y. Supp. 668 (1910).

${ }^{4}$ I Mer. 572 (Eng. I816). The Clayton case rule is still said to be followed where the money of the wrongdoer is not in the commingled mass. This is criticized by Scott, supra note I6. 
tion must be considered depleted to the proportion of the surplus withdrawal over what might have lawfully been withdrawn. In applying that line of reasoning the courts have gone to the extent of holding that any subsequent replacement, even though it may be money belonging to the wrongdoer himself, could not be claimed by the party injured.50

A close scrutiny of the above proposition on logical grounds leads the writer to the conclusion that it is, as Ames has said, ${ }^{51}$ more fiction than fact or truth. The matter may be stated in syllogistic form thus:

All trustees are presumed to be honest.

An honest trustee will first draw his own money, or that which he may lawfully withdraw.

Therefore the defendant trustee must have drawn his own money or that which he might lawfully withdraw.

Evidently the logical inference from the first premise would be that the trustee is honest in all his dealings. Therefore, if by the second premise the trustee is presumed to be honest in his withdrawals, he must also be presumed to be honest in his replacement. In other words he must be taken to have the intention when he replaces the money that it should become appropriated to and part of the money of the person who had the equitable title when it was withdrawn. And that, it is submitted, is all that is legally necessary. ${ }^{52}$

${ }^{50}$ See James Roscoe (Bolton) Ltd. v. Winder, supra note 27 . See also cases cited in Scort, op. cit. supra note 2 , at $547 \mathrm{n}$.

${ }^{51}$ Ames, supra note 16.

${ }^{62}$ See James Roscoe (Bolton) Ltd. v. Winder, supra note 27 , suggesting that if there had been a separate trust account, subsequent payments into the account would be sufficient indication of intention to restore what was taken, and so impose a trust by way of substitution. To like effect, but presenting the negative aspect is $I n$ re Oatway, supra note 28 , which apparently repudiates the presumption when the intent is clearly the other way, $i$. e., to use the trust funds and not the trustee's own money. So also is In re Northrup et al., 152 Fed. 763 (N. D. N. Y. I907), where the court says, at 774: "It would be extremely and ridiculously technical to assert that where a wrongdoer, so far as he can, rights a wrong committed in converting the money of another, by substituting at a subsequent time other money of his own to make good that converted, the beneficial owner may not claim and hold the substituted money or property as impressed with precisely the same trust as the original fund . . . It does not lie with the wrongdoer, or his assignee or trustee in bankruptcy, who has made the substitution, to say that the substituted thing is neither the trust property itself nor its proceeds, nor property purchased with the proceeds. Having made the substitution, he should be and is estopped to deny the title of the owner of the original fund."

It would seem, though, that the court here is somewhat ambiguous in first using intent by way of marking out a substitution, and then allowing the latter to prevail as against a supposedily negative intent. But since intent determines substitution, that latter must stand or fall with it. Cf. In re McIntyre \& Co., I8I Fed. 960 (C. C. A. 2d, I9Io).

In another case, State Savings Bank v. Thompson, et al., $88 \mathrm{Kan}$. 46I, I28 Pac. I 120 (19r3) the court dealt with the proceeds of a sale of personal property made by an agent for his principal, where the agent used up the specific proceeds, later depositing other money as to which no superior rights attached, and the court held that the principal could claim a later deposit, saying at $464,128 \mathrm{Pac}$. at I121: "On the other hand, it has been frequently decided that a trustee in possession of funds belonging to another, . . . may restore the funds and substitute his own money in lieu thereof." See also Jeffray v. Towar, 63 N. J. Eq. 530, 53 Atl. I82 (1902) ; Baker v. New York National Exchange Bank, I00 N. Y. 3r, 2 N. E. 452 (I885). 
From another angle, that of withdrawal, aside from any question of replacement, the factual existence of the first premise may seriously be doubted, and, assumed as true, presents a still greater inherent fallacy when one attempts to apply it to certain situations. If the parties involved be the only depositor and depositee in question, the doctrine that the latter, being honest, would intend to use his own money first, would present no practical and logical difficulty. The same would also be true if the depositors are more than one but out of the number there was only one depositor whose money was accepted under fraudulent circumstances. In that case the other depositors' money, not being affected by fraud will have become the depositee's money, while he has become their debtor. The same might conceivably be true if there are several depositors affected by the fraud, provided that the money in the mixed mass had never fallen below what would be necessary to satisfy all the claims of these several depositors should they all claim to choose preferences on the ground of constructive trusts in their favor. But suppose, however, what would almost always be the case under modern banking practice and operation, that there was in the last situation not enough money all the time to have satisfied these several claims? For the purpose of illustration, let us designate these depositors as $A, B$, and $C$, whose deposits were $\$ 5000, \$ 3000$, and $\$ 2000$ respectively, and $D$ as the depositee bank, and let us assume that at one time or another while these accounts stood to the credit of the depositors, the funds in the bank were reduced to $\$ 5000$. If any one of the depositors had sued on his particular claim, he would have been entitled to assert his preference, because in any case there would have been enough money at all times in the bank to take care of the claims in question. Yet, so far as the presumption of honesty is concerned, $D$ could certainly not have been honest to $A, B$, and $C$, since he could not help knowing of the $\$ 5000$ shortage; that $\$ 5000$ would not belong to him or be considered as his money, if we assume that the whole $\$ 10,000$ was acquired under fraudulent circumstances. $D$ would then have to be presumed to be honest as to $A$, but dishonest as to $B$ and $C$, or honest as to either $B$ and $C$, or both, but dishonest as to $A$. We would then have the curious legal paradox of $D$ being honest and dishonest at the same time.

To escape this logical difficulty, two alternatives present themselves: either $D$ must be presumed to be dishonest as to all and to have intended to take and use his depositors' rather than his own money, which would make the raising of a trust impossible; or $D$ must be presumed to be honest as to all, and that in taking the money that he intended to replace it. The latter would in fact become the sine qua non of the former, and since the intent is the determining factor whether or not there was enough money continually to take care of all or some of the claims would become immaterial, provided there is enough at the time the assignment is made. One is thus forced to 
the conclusion that the requirement of there being enough money at all times in the bank to take care of a claim in question is logically meaningless and on principle unnecessary.

Turning to the requirement that there must be an augmentation of the assets of the bank, it likewise appears unsound on close examination. The practical consequence of this requirement would be to defeat a trust where there was nothing more than a shifting of credits and debits. ${ }^{53}$

The far-reaching effect of this consequence is obvious. It makes it possible for a bank to use any manner of fraud, so long as it can show that no actual money came to it (or is held for it) as a result of a given deposit. Since under the modern banking system transactions of this kind are quite frequent the extent of deposits that would be affected would be enormous. It would affect deposits where the maker or drawer and the payee or depositor deal with the same bank; and likewise where the drawee bank receives the deposit in the same instance; it would affect deposits of commercial paper, where the bank receiving the deposit forwards it for collection to an agency with whom it has an account and to whom it owes money, the paper when collected being credited by the agent to the forwarding bank. Also, it would affect deposits where several intervening banks or sub-agents are used in the process of collection, if the forwarding bank is a debtor of any or all of the sub-agents; and likewise, if the collecting bank, whether agent or subagent, although itself not a creditor, should credit collection to another of its clients to whom the forwarding bank owes money.

Looked at logically, this whole idea of requiring receipt of actual money by the insolvent bank itself or by someone acting as its agent is meaningless and without practical effect. As aptly pointed out by one court opposed to that idea, if an actual exchange of money would satisfy the requirement, to effect a transfer without such exchange is merely a time-saving device which avoids a useless procedure. ${ }^{54}$ In any one of the instances given above, the money might first have been made to come in the form of an actual cash deposit, which would have satisfied the requirement under discussion. For instance, if the drawer of a bill of exchange and the payee deal with the same bank, the former may have withdrawn the amount of the bill and paid it to the payee directly, and the latter may have instantly redeposited the sum thus obtained in the same bank to his own credit. That would have been an augmentation of the assets of the bank, and yet the bank would not have been any richer than if it had shifted the amount in question from the credit of the drawer to the credit of the payee. The situation is somewhat similar where the insolvent bank collects through another bank, a sub-agent to whom

* Clark Sparks \& Sons Mule \& Horse Co. v. Americus National Bank, stlpra note 26; Nyssa Arcadia Drainage District v. First National Bank, eti., supra note 2; Phoenix Title \& Trust Co. v. The Central Bank of Phoenix et al., 30 Ariz. 43I, 247 Pac. I097 (I926).

State v. McKinley County Bank, supra note 8. 
it owes money. The sub-agent bank would have turned the money collected over to the insolvent bank, which in its turn could have instantly paid back an equal amount out of the common mass. Technically there would have been an increase of the assets of the bank; in either case, however, the assets of the bank would have remained the same. The only practical difference is that of time, and that is distinctly in favor of a book transfer of credits. The same useless procedure migint have been gone through with an agent for the insolvent bank, but with no practical difference.

There is all the more reason for disregarding such useless procedure when dealing with courts of equity. As remarked by the court in State $v$. McKinley County Bank, ${ }^{55}$ the maxim "Equity considers that done which ought to be done" should be applicable to situations like this. A bank handling sums under circumstances such as would impress them with a trust must be considered as charged with a duty to preserve these sums so as to make them available to the parties entitled to them, and that duty would attach whether the sum in question has to come out of the mass or comes to the bank in the form of something new. In the latter case, the bank, if it were honest, would not have accepted the money offered as a deposit, or having accepted it, would express its intention to the depositors to keep it separate as a bailment or trust ; in the first instance, if it were honest, it would make immediate payment to the party entitled to it, or would separate the sum out of the general mass, signifying its intention thereafter to keep it for such party as a bailment or trust. In either case, if it does not do what in honesty it should and could have done, a court of equity should consider it as done.

Finally, is it equitable to allow a party to profit by its own act of misfeasance or malfeasance as against an innocent depositor? The argument is commonly advanced that after all it is not the guilty party, the bank itself, that would profit, but all the other depositors. But, would it be equitable to allow general creditors to profit at the expense of an innocent depositor who has, except as to a meaningless requirement, a better and prior right? Surely it is an $a$ fortiori case where the benefit accruing to the general creditors comes through or is a result of the bank's fraud. Furthermore, on principle, a creditor cannot claim more than what the bankrupt has, and an assignment in bankruptcy generally does not cover such property. ${ }^{56}$ It would seem, therefore, that there is no basis in principle or in practice for denying priority because of the nature of the shifting of credit.

Supra note 8.

${ }^{56}$ Gardner v. Rowe, 2 Sim. \& St. 346 (Eng. I825). 